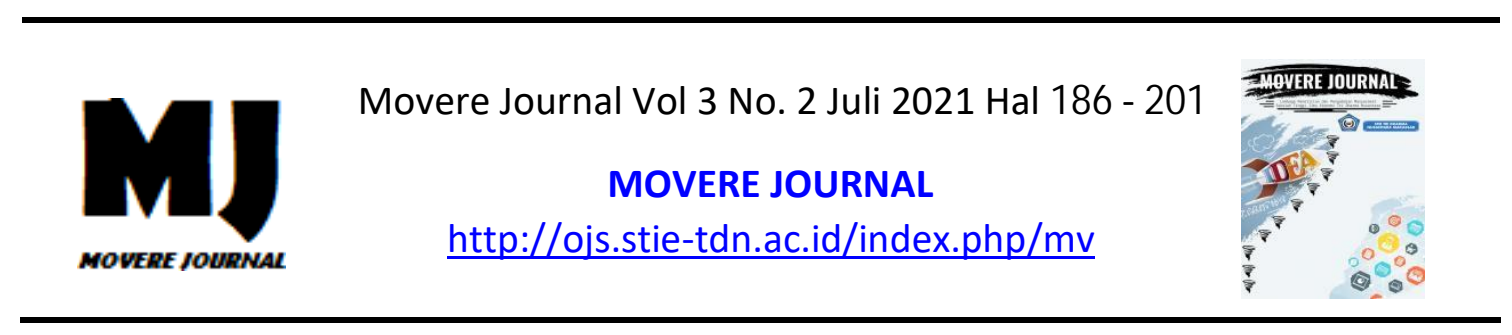

\title{
Pengaruh Faktor Fundamental dan Teknikal Terhadap Harga Saham Industri Perhotelan yang Terdaftar Di Bursa Efek Indonesia.
}

\author{
Monalisa \\ Akbid Nusantara Jaya \\ Email: monalisam337@gmail.com
}

\begin{abstract}
Abstrak : Penelitian ini bertujuan untuk menguji pengaruh faktor fundamental dan teknikal terhadap harga saham industri perhotelan yang terdaftar di bursa efek Indonesia. Penelitian ini merupakan penelitian kuantitatif dengan pendekatan kausalitas. Populasi dalam penelitian ini adalah seluruh perusahaan industri perhotelan yang terdaftar di Bura Efek Indonesia. Penelitian ini menggunakan teknik purposive sampling. Data yang digunakan dalam penelitian ini merupakan data sekunder yang didasarkan pada pengumpulan data laporan keuangan perusahaan industri perhotelan yang terdaftar di Bursa Efek Indonesia. Analisis data menggunakan analisi regresi linier berganda. Hasil penelitian menunjukkan bahwa : 1) return on assets, current ratio, debt to equity ratio, IHSG, dan volume perdagangan berpengaruh secara simultan terhadap harga saham, 2) return on assets berpengaruh positif dan signifikan terhadap harga saham, 3) debt to equity ratio berpengaruh positif dan signifikan terhadap harga saham, 4) current ratio berpengaruh negatif dan tidak signifikan terhadap harga saham, 5) indeks harga saham gabungan (IHSG) berpengaruh positif dan tidak signifikan terhadap harga saham dan 6) volume perdagangan berpengaruh negatif dan signifikan terhadap harga saham.
\end{abstract}

Kata Kunci : Harga saham, return on assets, debt to equity ratio, current ratio, indeks harga saham gabungan, volume perdagangan.

Abstract : This study aims to examine the effect of fundamental and technical factors toward the stock price of hotel industry listed on the Indonesian stock exchange. This is a quantitative research with a causal approach. The population in this research is all the companies of hotel industry registered in the Indonesian Stock Exchange. This research applied purposive sampling technique. The data used in this research is secondary data based on data collection of financial report of hotel industry companies registered on the Indonesia Stock Exchange. Data analysis used multiple linear regression analysis. The results of the research show that: 1) return on assets, current ratio, debt to equity ratio, JCI, and trading volume have a simultaneous effect toward the stock price, 2) return on assets has a positive and significant effect toward the stock price, 3) debt to equity ratio have positive and significant effect toward the stock price, 4) the current ratio has a negative and insignificant effect toward the share stock price, 5) the composite stock price index (CSPI) has a positive and insignificant effect toward the stock price and 6) trading volume has a negative and significant effect on stock price.

Keywords: stock price, return on assets, debt to equity ratio, current ratio, composite stock price index, trading volume. 


\section{PENDAHULUAN}

\section{A. Latar Belakang}

Pola perilaku harga saham menentukan pola return yang diterima dari saham tersebut. Untuk berinvestasi dalam bentuk sekuritas saham, seorang investor yang rasional akan menginvestasikan dananya dengan memilih saham-saham yang efisien, yang dapat memberikan return maksimal dengan tingkat risiko tertentu atau return tertentu dengan risiko yang seminimal mungkin. Harga saham sebagai representasi dari nilai perusahaan ditentukan oleh faktor internal perusahaan. Faktor internal perusahaan merupakan faktor fundamental yang sering dipakai sebagai dasar oleh para investor di pasar modal untuk mengambil keputusan investasinya. Di samping faktor fundamental, maka faktor teknikal juga merupakan faktor penting yang dapat mempengaruhi harga saham. faktor ini lebih bersifat teknis dan psikologis seperti, volume perdagangan saham, nilai transaksi perdagangan saham dan kecenderungan naik turunnya harga saham. Harga saham bisa naik bisa pula turun. Hal ini yang perlu disadari oleh para pemodal. Analisis terhadap faktorfaktor yang diperkirakan akan mempengaruhi harga saham, risiko yang ditanggung pemodal, merupakan faktor yang akan mempengaruhi perkembangan pasar modal. makroekonomi sebagai indikator yang dianggap berpengaruh terhadap return saham dan nilai perusahaan adalah: inflasi, suku bunga, kurs. (Afriyani 2018)

Menurut Jogiyanto (2008:126) terdapat dua macam analisis untuk menentukan nilai saham, yaitu terdiri dari informasi yang bersifat fundamental dan informasi yang bersifat teknikal. Informasi yang bersifat fundamental diperoleh dari internal perusahaan yang meliputi dividen dan tingkat pertumbuhan penjualan perusahaan, sedangkan informasi yang bersifat teknikal diperoleh dari luar perusahaan seperti ekonomi, politik, finansial dan lainnya.

Pada analisis fundamental pendekatan utama yang digunakan oleh para analis sekuritas adalah informasi laporan keuangan yang membantu dalam penganbilan keputusan investasi. Informasi ini berupa informasi akuntansi yang terangkum dalam laporan keuangan yang menyajikan informasi berguna untuk pengambilan keputusan berbagai pihak (Sugir, 2004). Bentuk informasi laporan keuangan tersebut berupa rasiorasio yang digunakan untuk mengukur prestasi keuangan perusahaan yang dipublikasikan untuk kepentingan investor. Sebuah laporan keuangan dapat diukur dan diinterpretasikan oleh rasio. Dalam rasio tersebut terdapat beberapa sub-sub rasio. Adapun yang termasuk faktor-faktor fundamental yang digunakan dalam penelitian ini adalah Return On Assets (ROA), Current Ratio, dan Debt to Equaty Rasio (DER).

Kenyataannya teori tersebut tidak sepenuhnya didukung oleh bukti empiris yang dilakukan beberapa peneliti sebelumnya. Hasil penelitian yang dilakukan Natarsyah (2000) menunjukkan bahwa ROA berpengaruh positif dan signifikan terhadap harga saham. Sedangkan penelitian yang dilakukan Gede (2009) menunjukkan ROA tidak berpengaruh signifikan terhadap harga saham. Penelitian yang dilakukan Puspasari (2005) menunjukkan bahwa Current Ratio tidak berpengaruh secara signifikan terhadap harga saham. Sedangkan penelitian yang dilakukan Dwi Wulandari (2009) menujukkan bahwa Current Ratio juga tidak berpengaruh secara signifikan terhadap harga saham. 
Menurut Dharmastuti (2004) rasio Debt to Equity Ratio (DER) dapat juga digunakan. DER adalah perbandingan antara hutang yang dimiliki perusahaan dan total ekuitasnya. DER mencerminkan kemampuan perusahaan dalam memenuhi seluruh kewajibannya yang ditunjukkan oleh beberapa bagian dari modal sendiri yang digunakan untuk membayar hutang. Rasio leverage yang cukup tinggi menunjukkan kinerja perusahaan yang semakin buruk, karena tingkat ketergantungan permodalan perusahaan terhadap pihak luar semakin besar. Dengan demikian apabila Debt to Equity Ratio (DER) perusahaan tinggi, ada kemungkinan harga saham perusahaan akan rendah karena jika perusahaan memperoleh laba, perusahaan cenderung untuk menggunakan laba tersebut untuk membayar utangnya dibandingkan dengan membagi deviden (Dharmastuti, 2004). Hasil penelitian yang berbeda juga ditemukan pada pengaruh Debt to Equity Ratio (DER). Penelitian yang dilakukan oleh Natarsyah S (2002), Puspasari (2005) dan Artha (2014) menunjukkan bahwa Debt to Equity Ratio (DER) berpengaruh signifikan terhadap harga saham. Sedangkan hasil yang berbeda ditemukan oleh Hijriah (2007), menyatakan bahwa faktor fundamental debt to equity ratio (DER) tidak berpengaruh terhadap harga saham.

Selain informasi fundamental, investor juga perlu mempertimbangkan informasi teknikal yang merupakan suatu informasi yang akan memberikan gambaran kepada investor untuk menentukan kapan pembelian saham dilakukan dan kapan saham tersebut dijual atau ditukar dengan saham yang lain agar memperoleh keuntungan yang maksimal. Analisis teknikal merupakan analisis terhadap data historis harga saham. Melalui data historis yang dimiliki, diharapkan dapat memprediksi arah pergerakan saham selanjutnya. Pendekatan ini menggunakan data pasar yang dipublikasikan seperti : harga saham, volume penjualan, indeks harga saham gabungan dan individu, serta faktor-faktor lain yang bersifat teknis. (Sony Siswoyo, 2013:63). Dalam penelitian ini dalam menentukan pengaruh informasi teknikal terhadap harga saham hanya akan memfokuskan pada volume penjualan dan indeks harga saham gabungan. Hasil penelitian yang tidak konsisten mengenai pengaruh volume penjualan terhadap harga saham yang dilakukan oleh Abidin (2016) menyatakan bahwa volume penjualan tidak berpengaruh terhadap harga saham sedangkan penelitian yang dilakukan oleh Dwi Wulandari (2009) menyatakan hal yang sama.

Analisis teknikal seringkali kontras dengan analisis fundamental yaitu studi atas faktor ekonomi yang diyakini beberapa analis mampu mempengaruhi harga dalam pasar keuangan.Para analis teknikal meyakini bahwa harga tersebut sudah mencerminkan semua pengaruh ekonomi tersebut sebelum investor menyadarinya.Beberapa pedagang menggunakan salah satu dari teknikal atau fundamental, namun beberapa lainnya menggabungkan keduanya dalam melakukan analisis (Budi Harsono, 2013:39).

Di pasar saham perusahaan yang telah go public dikelompokkan ke dalam beberapa sektor industri. Dari pengelompokan tersebut, industri perhotelan memiliki jumlah perusahaan yang paling besar, dan merupakan emiten terbesar dibanding industri lain. Berikut ini adalah data pergerakan saham perusahaan sektor perhotelan di Bursa Efek Indonesia. Menunjukkan rata-rata harga saham mengalami peningkatan dan berfluktuasi setiap tahunnya. Return on 
Assets pada perusahaan Perhotelan mengalami fluktuasi. Hal tersebut akan mengakibatkan tidak stabilnya kinerja keuangan yang dialami perusahaan Perhotelan yang terdaftar di Bursa Efek Indonesia.

Tetapi pada tahun 2010 dan 2014, yang harga sahamnya meningkat yang tidak dibarengi dengan kenaikan nilai Return On Assets, yang ada hanya terlihat penurunan Return On Assets (ROA), sehingga investor tidak tertarik dalam berinvestasi karena perusahaan dinilai memiliki Return On Assets (ROA) menurun yang mencerminkan apresiasi pasar dalam memberi nilai atau harga saham perusahaan dalam menghasilkan laba yang menurun. Fenomena yang terjadi pada tahun 2010 dan 2014, teori retrun on assets (ROA) yang menyatakan bahwa apabila ROA tinggi maka harga saham juga akan tinggi, namun pada tabel diatas bahwa ROA dan harga saham menunjukkan kebalikan dari teori tersebut.

Berdasarkan latar belakang yang telah dijabarkan beserta hasil penelitian yang variatif dan tidak konsisten tersebut mendorong untuk dilakukan penelitian lanjutan dengan dengan mengambil sampel penelitian pada perusahaan perhotelan yang tercatat pada Bursa Efek Indonesia dengan judul penelitian "Pengaruh Faktor Fundamental dan Teknikal Terhadap Harga Saham Industri Perhotelan yang Terdaftar Di Bursa Efek Indonesia".

\section{B. Rumusan Masalah}

Berdasarkan uraian di atas, maka pokok permasalahan dalam penelitian ini akan dirumuskan dalam bentuk pertanyaan, sebagai berikut:
1. Apakah retrun on assets berpengaruh terhadap harga saham industri perhotelan di Bursa efek Indonesia ?

2. Apakah current ratio berpengaruh terhadap harga saham industri perhotelan di Bursa Efek Indonesia?

3. Apakah debt to equity ratio berpengaruh terhadap harga saham industri perhotelan di Bursa Efek Indonesia?

4. Apakah Index Harga Saham gabungan berpengaruh terhadap harga saham industri perhotelan di Bursa Efek Indonesia?

5. Apakah volume perdagangan saham berpengaruh terhadap harga saham industri perhotelan di Bursa Efek Indonesia?

\section{TINJAUAN PUSTAKA}

\section{A. Teori Sinyal (Signaling Theory)}

Signalling Theory merupakan teori yang membahas mengenai bagaimana perusahaan memberikan informasi atau sinyal baik positif maupun negatif bagi pemegang saham (Scott dalam Himawan dan Christiawan, 2016). Signaling theory menurut beberapa literatur merupakan efek yang terjadi sebagai akibat dari pengumuman laporan keuangan yang ditangkap oleh para pengguna, khususnya para pelaku bursa. Adanya informasi keuangan tersebut menimbulkan efek, yang akan ditangkap sebagai signal oleh para pelaku bursa sebagai peluang atau sebagai ancaman ke depan berkaitan dengan prospek investasi yang akan dilakukannya. Oleh karena itu, signaling effect dihasilkan oleh informasi baru dari pengumuman laporan keuangan, dan bukan oleh sebuah issue yang terjadi (Penman,2003). Investment (Investasi) adalah studi yang mempelajari proses investasi, proses investasi adalah urutan tindakan yang seharusnya dilakukan oleh 
pemodal yang melakukan investasi pada aset keuangan. Saham merupakan sala satu bentuk aset keuangan yang dapat diperdagangkan pada pasar modal. Karakteristik saham adalah sekuritas yang memberikan imbal hasil yang tidak tetap. Kemampuan untuk mengidentifikasi faktor-faktor yang paling berperan dalam menentukan kinerja portofolio, merupakan kajian akademis dalam dua dekade terakhir. Pengujian terhadap perilaku kinerja portofolio saham akan dapat membantu dalam mengevaluasi dan menginterpretasikan faktor-faktor penentunya. Jika ditemukan bahwa portofolio saham menunjukkan perubahan kinerja yang besar, berarti konsistensi dengan faktor-faktor yang berkonstribusi terhadap komponen penting pergerakan harga saham. (Afriyani 2018)Afriyani. 2018. 'Influence of Micro Fundamental Factors and Macroeconomics on Share Return and Manufacturing Value of Companies Listed in Indonesia Stock Exchange (IDX).' Quest journal of research in Humanities and social Science (JRHSS) 6(5): 49-57.

\section{B. Faktor Fundamental}

Faktor fundamental dibagi menjadi dua yaitu faktor fundamental yang bersifat internal yang memberikan informasi tentang kinerja perusahaan dan faktorfaktor yang bersifat eksternal yang meliputi kondisi perekonomian secara umum. Untuk melihat kinerja perusahaan melalui rasio keuangan, biasanya dibandingkan dengan perusahaan lainnya dalam industri yang sama untuk menemukan posisi perusahaan apakah "normal" atau "tidak normal". Selain dibandingkan dengan perusahaan lain, kinerja keuangan juga dapat dibandingkan dengan pasar (diwakili dengan indeks). Rasio secara garis dasar di bagi dalam lima kategori utama antara lain, yaitu: profitability (keuntungan), price (harga), liquidity (likuiditas), leverage (dukungan), dan efficiency (efisiensi).

\section{Faktor Teknikal}

\section{Definisi Analisis Teknikal}

Secara umum analisis teknikal merupakan sebuah metode peramalan gerak harga saham, indeks atau instrumen keuangan lainnya dengan menggunakan grafik berdasarkan data historis. Jadi, analisis teknikal adalah analisis untuk memprediksi pergerakan harga saham di masa yang akan datang atas dasar past performance atau pola pegerakan harga dan volume perdagangan yang telah terjadi sebelumnya (Budi Harsono,2013:39). Analisis teknikal mempelajari saham dan bursa dengan berdasarkan pada penawaran (supply) dan permintaan (demand). Dalam analisis teknikal, pekerjaan baru dimulai setelah harga terbentuk di pasar atau di bursa.

Dengan analisis teknikal investor dapat mengambil manfaat lebih jauh untuk menentukan kapan investor akan membeli atau menjual saham yang dikatakan under /over valued untuk mendapatkan maximum return. investor dapat menentukan kapan membeli saham pada tingkat harga terendah dan kapan menjual saham pada tingkat harga tertinggi dengan melihat tren harga saham yang terjadi. (http://www.bumianyar.com/)

\section{Retrun On Assets terhadap harga saham}

Tandelilin (2001:240) menyatakan bahwa return on assets menggambarkan sejauhmana kemampuan asset-aset yang dimiliki perusahaan bisa menghasilkan 
laba. Semakin tinggi rasio ROA menunjukkan bahwa perusahaan semakin efektif dalam memanfaatkan aktiva untuk menghasilkan laba bersih setelah pajak, yang juga dapat diartikan bahwa kinerja perusahaan semakin efektif. Hal ini selanjutnya akan meningkatkan daya tarik perusahaan kepada investor dan berdampak pada harga saham dari perusahaan tersebut di pasar modal juga akan semakin meningkat, dengan kata lain ROA akan berpengaruh terhadap harga saham perusahaan.

Rahmi et al. (2013) melakukan penelitian terhadap variabel ROA, hasil penelitian yang ditemukan adalah variabel ROA berpengaruh positif terhadap harga saham. Kemudian penelitian yang dilakukan oleh Natarsyah S (2002) dengan hasil penelitian yang konsisten yaitu ROA berpengaruh terhadap harga saham.

\section{E. Current Ratio terhadap harga saham}

Kemampuan likuiditas keuangan antar perusahaan cenderung berbeda antara satu industri dan industri lainnya. Kriteria perusahaan yang mempunyai posisi keuangan kuat adalah mampu memenuhi kewajiban keuangan kepada pihak luar secara tepat waktu, mampu menjaga kondisi modal kerja yang cukup, mampu membayar bunga dan kewajiban dividen yang harus dibayarkan, dan menjaga posisi kredit utang yang aman. Semakin tinggi angka rasio likuiditas, akan semakin baik bagi investor, perusahaan yang diminati investor adalah perusahaan yang mempunyai rasio likuiditas cukup tinggi (Rahardjo, 2006). Semakin baik rasio current rationya maka akan semakin likuid perusahaan tersebut, sehingga dapat meningkatkan minat masyarakat untuk berinvestasi pada perusahaan tersebut. Hal ini akan berdampak positif pada harga saham. Jadi, current ratio diperkirakan berpengaruh positif terhadap harga saham, artinya ketika CR mengalami kenaikan, diikuti dengan kenaikan harga saham.

Penelitian yang dilakukan oleh Dewi dan Wahyudi (2012), Puspasari (2005), dan Dwi Wulandari (2009) dengan hasil penelitian yang bertentangan dengan teori yaitu current ratio tidak berpengaruh signifikan terhadap harga saham.

\section{harga saham}

Debt to Equity Ratio terhadap

Secara teoritis, Walsh (2003:118) menyatakan debt to equity ratio yang lebih dikenal dalam bahasa Indonesia dengan Rasio "Utang terhadap ekuitas" merupakan salah satu ukuran paling mendasar dalam keuangan perusahaan. DER mencerminkan kemampuan perusahaan dalam memenuhi seluruh kewajibannya, yang ditunjukkan oleh berapa bagian modal sendiri yang digunakan untuk membayar hutang. Bagi investor, semakin besar rasio DER akan semakin tidak menguntungkan karena semakin besar risiko yang ditanggung atas kegagalan yang mungkin terjadi di perusahaan (Kasmir, 2007:158). Semakin besar DER, maka semakin rendah harga saham perusahaan karena perusahaan harus membayar utang dan investor semakin tidak menarik untuk membeli saham perusahaan.

Penelitian mengenai debt to equity ratio pernah dilakukan oleh Rahmi et al. (2013) menyatakan bahwa DER berpengaruh signifikan terhadap harga saham. Sejalan dengan penelitian Artha et al. (2014), Puspasari (2005) dengan konsisten menyatakan bahwa debt to equity ratio berpengaruh signifikan terhadap harga saham. 


\section{F. Indeks Harga Saham Gabungan terhadap harga saham}

Kenaikan indeks harga saham gabungan sepanjang waktu tertentu, tentunya mendatangkan kondisi investasi dan perekonomian negara dalam keadaan baik. Sebaliknya jika turun berarti iklim investasi sedang buruk. Kondisi demikian akan mempengaruhi naik atau turunnya harga saham di pasar bursa.

\section{G. Volume perdagangan terhadap harga saham}

"Trading volume is number of shares stocks or indexs traded" (Jones et.al, 2009:447). Volume perdagangan merupakan banyaknya lembar saham yang diperdagangkan. "Trading volume is defined as the number shares bought and sold each day" (Abbondante, 2010:1). Volume perdagangan saham dapat diartikan sebagai banyaknya lembar saham dari suatu emiten atau perusahaan yang diperjual-belikan di pasar modal setiap harinya dengan tingkat harga yang telah disepakati oleh pihak penjual dan pembeli saham melalui broker(perantara) perdagangan saham. Susanto dan Sabardi (2010:104) menyatakan bahwa secara historis volume perdagangan saham mempunyai kaitan dengan harga pasar di bursa, dikarenakan volume perdagangan saham dianggap sebagai ukuran dari kekuatan atau kelemahan pasar sesuai dengan hukum penawaran dan permintaan. Penelitian yang dilakukan Abidin et al. (2016) menyatakan bahwa Volume perdagangan secara parsial berpengaruh negatif terhadap harga saham, adapun penelitian yang dilakukan oleh Dwi Wulandari (2009) menyatakan hal yang sama.

\section{KERANGKA KONSEPTUAL DAN HIPOTESIS.}

Berdasarkan pada latar belakang penelitian dan hasil telaah pustaka, diketahui bahwa teori-teori yang membahas mengenai faktor yang dapat mempengaruhi harga saham memberikan pandangan yang berbeda, bahkan saling bertentangan. Penelitian ini bertujuan untuk menguji kembali secara empiris tentang teori mana yang lebih tepat dalam menjelaskan faktor yang dapat mempengaruhi harga saham yang dijalankan oleh industri perhotelan di Bursa efek Indonesia. Adapun kerangka konseptual penelitian ini digambarkan pada model berikut ini:

Gambar 1: Kerangka Konseptual

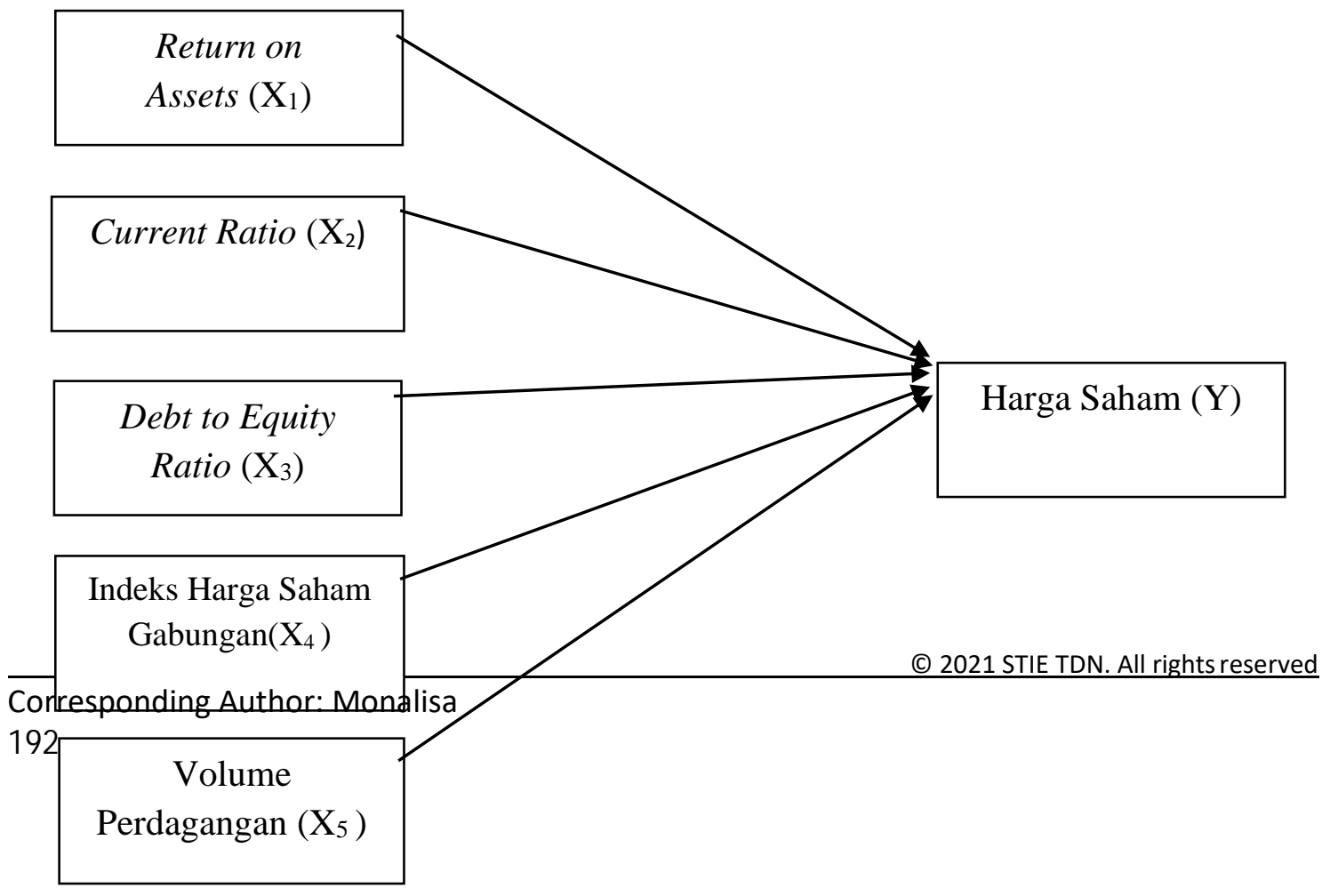


Berdasarkan penjelasan teori sebelumnya dan hasil-hasil penelitian sebelumnya, dan kerangka konseptual maka hipotesis yang diajukan ialah:

$\mathrm{H}_{1}$ : Return on assets berpengaruh terhadap harga saham industri perhotelan di Bursa efek Indonesia.

$\mathrm{H}_{2}$ : Current ratio berpengaruh terhadap harga saham industri perhotelan di Bursa efek Indonesia.

$\mathrm{H}_{3}$ : Debt to equity ratio berpengaruh terhadap harga saham industri perhotelan di Bursa efek Indonesia.

$\mathrm{H}_{4}$ : Indeks harga saham gabungan berpengaruh terhadap harga saham industri perhotelan di Bursa efek Indonesia.

$\mathrm{H}_{5}$ : Volume perdagangan berpengaruh terhadap harga saham industri perhotelan di Bursa efek Indonesia.

\section{IV.METODE PENELITIAN}

Penelitian Ini Merupakan jenis penelitian kuantitatif Deskriptif, adapun objek penelitian dan populasi penelitian ini adalah Perusahaan industri perhotelan yang terdaftar di Bursa Efek Indonesia tahun 2011-2015, Pengambilan sampel dilakukan secara purposive sampling. Berdasarkan kriteria dari 21 populasi penelitian tersebut, maka terdapat sebanyak 15 perusahaan yang memenuhi syarat untuk dijadikan sampel dalam penelitian. Adapun jenis data yang digunakan dalam penilitian ini yaitu data sekunder dan sumber data yang digunakan adalah data keuangan perusahaan yang yang di peroleh dari website Indonesia Stock Exchange (IDX) yaitu www.idx.co.id.

Teknik analisis data yang digunakan dalam peneltian ini adalah menggunakan analisis kuantitatif. Analisis kuantitatif merupakan suatu bentuk analisis yang diperuntukkan bagi data yang besar yang dikelompokkan ke dalam kategorikategori yang berwujud angka-angka. Metode analisis data menggunakan analisis deskriptif, uji asumsi klasik dan uji hipotesis dengan bantuan komputer melalui program IBM SPSS 20 for windows.

Untuk memudahkan proses analisis dipergunakan aplikasi SPSS dengan Model Persamaan regresi, Analisis Regresi Linier Berganda (Multiple Regression Analysis). Analisis regresi linier berganda (multiple regression) dilakukan untuk menguji pengaruh dua atau lebih variabel independen (explanatory) terhadap satu variabel dependen. Model regresi berganda dalam pernyataan ini dinyatakan sebagai berikut :

$\mathrm{Y}=\alpha+\beta 1 \mathrm{X} 1+\beta 2 \mathrm{X} 2+\beta 3 \mathrm{X} 3+\beta 4 \mathrm{X} 4$

$+\beta 5 \mathrm{X} 5+\mathrm{e}$.

Menyelesaikan analisis data menggunakan Software Program SPSS 20 (Statistical Product and Service Solution) dan semua hasil output data yang dihasilkan kemudian diintepretasikan satu per satu. Uji regresi berganda dilakukan untuk menguji hipotesis $\mathrm{H}_{1}$ sampai $\mathrm{H}_{5}$.

Perhitungan dengan SPSS 20 
akan diperoleh keterangan atau hasil tentang koefisien determinasi $\left(\mathrm{R}^{2}\right)$, Uji F, Uji t.

\section{Variabel dan Pengukurannya.}

Agar penelitian ini dapat dilaksanakan sesuai dengan yang diharapakan, maka perlu dipahami berbagai unsur-unsur yang menjadi dasar dari suatu penelitian ilmiah yang termuat dalam operasionalisasi variabel penelitian Secara lebih rinci, operasionalisasi variabel yang digunakan dalam penelitian ini sebagai berikut:

\section{Harga Saham (Y)}

Menurut Sunariyah (2006:128), harga saham adalah harga suatu saham pada pasar yang sedang berlangsung di bursa efek. Dalam penelitian ini menggunakan harga dari suatu saham yang ditentukan pada saat pasar saham sedang berlangsung dengan berdasarkan kepada permintaan dan penawaran pada saham yang dimaksud, dengan harga saham yang diwakili oleh harga saham penutupan (closing price) pada tutup tahun, karena harga saham pada tutup tahun dianggap dapat mewakili fluktuasi harga saham yang terjadi dalam satu periode (diukur dalam satuan rupiah).

2. Retrun On Assets (X1)

Return On Assets (ROA) adalah rasio yang digunakan untuk mengukur kemampuan asset perusahaan dalam menghasilkan laba bersih. ROA juga merupakan indikator efisiensi penggunaan total asset perusahan. ROA dapat dihitung dengan rumus (Husnan, 2001:339) :

$$
\text { ROA }=\frac{\text { Laba Setelah Pajak }}{\text { Total Aktiva }} \times 100 \%
$$

\section{Current Ratio (X2)}

Current ratio (CR) merupakan perbandingan antara aktiva lancar dan kewajiban lancar dan merupakan ukuran yang paling umum digunakan untuk mengetahui kesanggupan suatu perusahaan memenuhi kewajiban jangka pendeknya. Rasio ini salah satu dari rasio likuiditas. Adapun skala pengukuran current ratio dengan rumus sebagai berikut (Munawir, 2004:104)

Current Ratio $=\frac{\text { aktiva lancar }}{\text { utang lancar }} X_{100 \%}$

\section{Debt to Equity Rasio (X3)}

Debt to equity ratio (DER) adalah perbandingan total hutang yang dimiliki perusahaan dengan total ekuitas. Satuan pengukuran DER adalah dalam persentase, secara matematis rumus untuk menghitung debt to equity ratio bisa ditulis sebagai berikut (Ang, 1997) :

DER $=\frac{\text { Total Debt }}{\text { Total Equity }} \times 100 \%$

\section{Indeks Harga Saham Gabungan} (X4)

Indeks harga saham gabungan merupakan Indikator pergerakan harga saham yang tercatat di bursa dan merupakan indeks gabungan dari seluruh jenis saham yang tercatat di Bursa Efek Indonesia.Rumus yang digunakan untuk menghitung IHSG :

IHSG $=\frac{\sum \text { Kapitalisasi pasar }}{\sum \text { Nilai Pasar }} \times 100 \%$

\section{Volume Perdagangan (X5)}

Volume perdagangan saham adalah merupakan rasio antara jumlah lembar saham yang diperdagangkan pada waktu tertentu terhadap jumlah saham yang beredar pada waktu tertentu (Suad Husnan et al., 2005). Dirumuskan sebagai berikut :

$\mathbf{V P}=\frac{\text { Volume Perdagangan Individu }}{\text { Volume Perdagangan Sektoral }}$

\section{HASIL PENELITIAN DAN PEMBAHASAN}


A. Analisis Data

1. Uji Hipotesis

\begin{tabular}{|c|c|c|c|c|c|c|}
\hline & \multicolumn{6}{|c|}{$\mathrm{ANOVA}^{\mathbf{a}}$} \\
\hline & Model & $\begin{array}{c}\text { Sum of } \\
\text { Squa } \\
\text { res }\end{array}$ & $\mathrm{Df}$ & $\begin{array}{c}\text { Mean } \\
\text { Squ } \\
\text { are }\end{array}$ & $\mathrm{F}$ & Sig. \\
\hline Mod & $\begin{array}{r}\text { Regressi } \\
\text { on }\end{array}$ & 9.207 & 5 & 1.841 & 9.786 & $.000^{\mathrm{b}}$ \\
\hline el & Residual & 12.796 & 68 & .188 & & \\
\hline 1 & Total & 22.003 & 73 & & & \\
\hline
\end{tabular}

a. Predic a. Dependent Variable: LN_hs

b. Predictors: (Constant), LN_vp,

LN_ihsg, LN_roa, LN_der, LN_cr

Teknik analisis yang digunakan untuk menguji hipotesis $\mathrm{H}_{1}, \mathrm{H}_{2}, \mathrm{H}_{3}, \mathrm{H}_{4}$ dan $\mathrm{H}_{5}$ menggunakan analisis regresi linier berganda dengan meregresikan variabel independen (rasio return on assets,current ratio,debt to equity ratio, IHSG, dan volume perdagangan) terhadap variabel dependen (harga saham). Uji hipotesis ini dibantu dengan menggunakan program SPSS versi 20. Hasil pengujian tersebut ditampilkan sebagai berikut :

\section{Tabel 1}

\section{Hasil Uji Koefisien Determinasi $\left(\mathbf{R}^{\mathbf{2}}\right)$}

\section{Sumber: Output SPSS 20}

Berdasarkan tabel diatas nilai $\mathrm{R}$ adalah 0,647 menurut pedoman interpretasi koefisien korelasi, angka ini termasuk kedalam kategori korelasi berpengaruh korelasi berpengaruh kuat karena berada pada interval 0,60-0,799. Hal ini menunjukkan bahwa rasio return on assets, current ratio, debt to equity ratio, IHSG, dan volume perdagangan berpengaruh kuat terhadap harga saham.

Berdasarkan hasil uji koefisien deteminasi diatas, nilai $\mathrm{R}^{2}$ (Adjusted $R$ Square) dari model regresi digunakan untuk mengetahui seberapa besar kemampuan variabel bebas (independent) dalam menerangkan variabel terikat (dependent). Dari tabel diatas diketahui bahwa nilai $\mathrm{R}^{2}$ sebesar 0,376 , hal ini berarti bahwa $37,6 \%$ yang menunjukkan bahwa harga saham dipengaruhi oleh variabel rasio return on assets, current ratio, debt to equity ratio, IHSG, dan volume perdagangan. Sisanya sebesar $62,4 \%$ dipengaruhi oleh variabel lainyang belum diteliti dalam penelitian ini.

\section{Tabel 2.}

Hasil Uji F - Uji Simultan

Sumber: Output SPSS 20

Berdasarkan tabel diatas dapat dilihat bahwa dalam pengujian regresi berganda menunjukkan hasil $\mathrm{F}$ hitung sebesar 9,786 dengan tingkat signifikansi 0,000 yang lebih kecil dari 0,05 , dimana nilai $\mathrm{F}$ hitung lebih besar dari nilai $F$ tabelnya sebesar 3,13 (df1=3-1=2 dan df2=75-4=71), maka $\mathrm{H}_{\mathrm{o}}$ ditolak dan $\mathrm{H}_{\mathrm{a}}$ diterima. Berarti variabel rasio return on assets, current ratio, debt to equity ratio, IHSG, dan volume perdagangan secara bersama-sama berpengaruh terhadap harga saham.

\section{Tabel 3}

\section{Hasil Uji T Hitung}

Sumber: Output SPSS 20

Berdasarkan tabel 3 diatas dapat dianalisis model estimasi sebagai berikut :

$$
Y=-0,429+0,451 X_{1}-0,058 X_{2}+0,431
$$

$\mathrm{X}_{3}+1,176 \mathrm{X}_{4}-0,073 \mathrm{X}_{5}+\mathrm{e} \ldots(1)$

Dari persamaan di atas dapat dijelaskan bahwa :

Coefficients $^{\mathrm{a}}$

\begin{tabular}{|c|c|c|c|c|c|}
\hline \multirow[t]{2}{*}{ Model } & \multicolumn{2}{|c|}{$\begin{array}{l}\text { Unstandardized } \\
\text { Coefficients }\end{array}$} & \multirow{2}{*}{\begin{tabular}{|c} 
Standardiz \\
ed \\
Coef \\
ficie \\
nts \\
Beta \\
\end{tabular}} & \multirow[t]{2}{*}{$\mathrm{t}$} & \multirow[t]{2}{*}{ Sig. } \\
\hline & B & Std. Error & & & \\
\hline $\begin{array}{r}\text { (Consta } \\
n t)\end{array}$ & -.429 & 4.241 & & -.101 & .920 \\
\hline LN_roa & .451 & .112 & .470 & 4.018 & .000 \\
\hline LN_cr & -.058 & .362 & -.018 & -.160 & .874 \\
\hline LN_der & .431 & .206 & .234 & 2.088 & .041 \\
\hline LN_ihs & 1.176 & 1.160 & .095 & 1.014 & .314 \\
\hline LN_vp & -.073 & .028 & -.240 & 2.559 & .013 \\
\hline
\end{tabular}


1) Nilai konstanta sebesar $-0,429$ mengindikasikan bahwa jika variabel independen (rasio return on assets,current ratio,debt to equity ratio, IHSG, dan volume perdagangan) adalah nol maka nilai perusahaan akan terjadi sebesar 0,429 .

2) Koefisien regresi variabel return on assets (X1) sebesar 0,451 mengindikasikan bahwa setiap kenaikan satu satuan variabel rasio return on assets akan meningkatkan harga saham sebesar 0,451 .

3) Koefisien regresi variabel current ratio $(\mathrm{X} 2)$ sebesar 0,058 dengan tanda negative menunjukkan arah hubungan yang berlawanan arah hal ini berarti mengindikasikan bahwa setiap kenaikan satu satuan variabel current ratio akan mengurangi harga saham sebesar 0,058 .

4) Koefisien regresi variabel debt to equity ratio (X3) sebesar 0,431 mengindikasikan bahwa setiap kenaikan satu satuan variabel debt to equity ratio akan meningkatkan harga saham sebesar 0,431.

5) Koefisien regresi variabel IHSG (X4) sebesar 1,176 mengindikasikan bahwa setiap kenaikan satu satuan variabel IHSG akan meningkatkan harga saham sebesar 1,176.

6) Koefisien regresi variabel volume perdagangan (X5) sebesar $-0,073$ mengindikasikan bahwa setiap kenaikan satu satuan variabel volume perdagangan akan mengurangi harga saham sebesar $-0,073$.

Hasil interpretasi atas hipotesis penelitian $\left(\mathrm{H}_{1}, \mathrm{H}_{2}, \mathrm{H}_{3}, \mathrm{H}_{4}\right.$ dan $\left.\mathrm{H}_{5}\right)$ yang diajukan dapat dilihat sebagai berikut:

1) Return on assets berpengaruh terhadap harga saham $\left(\mathrm{H}_{1}\right)$

Berdasarkan tabel 12 dapat dilihat bahwa variabel return on assets memiliki $\mathrm{t}$ hitung $<\mathrm{t}$ tabel yaitu $\mathrm{t}$ hitung sebesar 4.018sementara t tabel dengan sig. $\alpha=0,05$ dan df $=n-k$, yaitu $75-1=74$ sebesar 1,666 dengan tingkat signifikansi sebesar 0,000 yang lebih kecil dari 0,05 , maka $\mathrm{H}_{\mathrm{a}}$ diterima. Ini berarti struktur mo return on assets dal bengaruh positif dan signifikan terhadap harga saham. Dengan demikian hipotesis pertama yang menyatakan return on assets berpengaruh terhadap harga saham terbukti. Hasil penelitian ini menunjukkan bahwa return on assets berimplikasi terhadap harga saham.

2) Current ratio berpengaruh terhadap harga saham $\left(\mathrm{H}_{2}\right)$

Berdasarkan tabel dapat dilihat bahwa variabel kebijakan dividen memiliki $\mathrm{t}$ hitung sebesar -.160< t tabel 1,666 dengan tingkat signifikansi 0,874 yang lebih besar dari 0,05, maka Ha ditolak. Hal ini berarti current ratio berpengaruh negatif dan tidak signifikan terhadap harga saham. Dengan demikian hipotesis kedua yang menyatakan current ratio berpengaruh terhadap harga saham tidak terbukti.

3) Debt to equity ratio berpengaruh terhadap harga saham $\left(\mathrm{H}_{3}\right)$

Berdasarkan tabel dapat dilihat bahwa variabel debt to equity ratio memiliki t hitung sebesar $2.088<\mathrm{t}$ tabel 1,666 dengan tingkat signifikansi 0,041 yang lebih kecil dari 0,05 , maka $\mathrm{Ha}$ diterima. Hal ini berarti debt to equity ratio berpengaruh positif dan signifikan terhadap harga saham. Dengan demikian hipotesis ketiga yang menyatakan debt to equity ratio berpengaruh terhadap harga saham terbukti.

4) IHSG berpengaruh terhadap harga saham $\left(\mathrm{H}_{4}\right)$

Berdasarkan tabel dapat dilihat bahwa variabel kebijakan dividen memiliki $t$ 
hitung sebesar $1.014<\mathrm{t}$ tabel 1,666 dengan tingkat signifikansi 0,314 yang lebih besar dari 0,05, maka Ha ditolak. Hal ini berarti IHSG berpengaruh positif dan tidak signifikan terhadap harga saham. Dengan demikian hipotesis keempat yang menyatakan $I H S G$ berpengaruh terhadap harga saham tidak terbukti.

5) Volume perdagangan berpengaruh terhadap harga saham $\left(\mathrm{H}_{5}\right)$

Berdasarkan tabel dapat dilihat bahwa variabel volume perdagangan memiliki $\mathrm{t}$ hitung sebesar $2.559<\mathrm{t}$ tabel 1,666 dengan tingkat signifikansi 0,013 yang lebih kecil dari 0,05, maka Ha diterima. Hal ini berarti volume perdagangan berpengaruh negatif dan signifikan terhadap harga saham. Dengan demikian hipotesis kelima yang menyatakan volume perdagangan berpengaruh terhadap harga saham terbukti.

\section{B. Pembahasan Penelitian}

Penelitian mengenai harga saham pada perusahaan industri perhotelan di bursa efek Indonesia, yang melibatkan pengaruh variabel bebas (rasio return on assets, current ratio, debt to equity ratio, IHSG, dan volume perdagangan) terhadap variabel dependen (harga saham), dapat dibuat pembahasan sebagai berikut:

1. Pengaruh return on assets terhadap harga saham pada perusahaan industri perhotelan di bursa efek Indonesia

Hipotesis pertama yang diajukan pada penelitian ini adalah bahwa return on assets berpengaruh terhadap harga saham pada industri perhotelan di bursa efek Indonesia tahun 20112015.Berdasarkan hasil analisis menunjukkan bahwa return on assets berpengaruh positif dan signifikan terhadap harga saham pada industri perhotelan di bursa efek Indonesia tahun 2011-2015.

Return on assets menggambarkan sejauhmana kemampuan asset-aset yang dimiliki perusahaan bisa menghasilkan laba. Semakin tinggi rasio ROA menunjukkan bahwa perusahaan semakin efektif dalam memanfaatkan aktiva untuk menghasilkan laba bersih setelah pajak, yang juga dapat diartikan bahwa kinerja perusahaan semakin efektif. Hal ini selanjutnya akan meningkatkan daya tarik perusahaan kepada investor dan berdampak pada harga saham dari perusahaan tersebut di pasar modal juga akan semakin meningkat, dengan kata lain ROA akan berpengaruh terhadap harga saham perusahaan.

Para investor akan lebih mencari perusahaan dengan tingkat profitabilitas yang tinggi, karena dianggap mampu memberikan return yang tinggi, bagi para kreditor laba yang dihasilkan perusahaan akan digunakan untuk membayar tingkat bunga dan pokok pinjaman, sehingga kreditor mengharapkan peningkatan laba perusahaan. Hal ini sesuai dengan hasil penelitian yang menunjukan bahwa ROA berpengaruh positif terhadap nilai perusahaan yang berarti peningkatan ROA akan mempengaruhi peningkatan harga saham perusahaan secara signifikan. Hasil penelitian ini sejalan dengan hasil penelitian yang dilakukan oleh Rahmi et al. (2013) dan Natarsyah S (2002) yang menyatakan bahwa return on assets berpengaruh signifikan terhadap saham.

2. Pengaruh current ratio terhadap harga saham pada perusahaan industri perhotelan di bursa efek Indonesia Hipotesis kedua yang diajukan pada penelitian ini adalah bahwa current 
ratio berpengaruh terhadap harga saham pada industri perhotelan di bursa efek Indonesia tahun 20112015. Berdasarkan hasil analisis menunjukkan bahwa current ratio berpengaruh negatif dan tidak signifikan terhadap harga saham pada industri perhotelan di bursa efek Indonesia tahun 2011-2015.

Hasil penelitiannya menyatakan bahwa current ratio tidak berpengaruh signifikan terhadap harga saham. Current ratio yaitu kemampuna aktiva lancar perusahaan dalam memenuhi kewajiban jangka pendek dengan aktiva lancar yang dimiliki. Likuiditas jangka pendek tersebut sangat masalah jika arus kas jangka pendek dapat mengakibatkan perusahaan bangkrut. Semakin tinggi current ratio semakin besar kemampuan perusahaan untuk membayar kewajiban jangka pendek (Darsono dan Ashari (2005). Current ratio merupakan rasio likuiditas dimana para kreditor mengukur operasi perusahaan dengan melihat apakah aktiva lancar perusahaan dapat memenuhi kewajiban jangka pendeknya saat kewajiban jangka pendek ini segera ditagih atau saat jatuh tempo. Karena semakin tinggi current ratio maka semakin besar kemampuan perusahaan dalam melunasi hutang-hutangnya. Maka para kreditor dapat mempertimbangkan untuk memberikan pinjaman bagi perusahaan, tapi untuk para investor current ratio tidak memiliki pengaruh dikarenakan investor hanya melihat pada kegiatan usaha perusahaan tanpa melihat likuiditas perusahaan. Sehingga dari penelitian ini menunjukan bahwa variabel current ratio tidak digunakan oleh para investor sebagai pertimbangan dalam berinvestasi pada suatu perusahaan. Hasil penelitian ini sejalan dengan hasil penelitian yang dilakukan oleh Dewi dan Wahyudi (2012), Puspasari (2005), dan Dwi Wulandari (2009) dengan hasil penelitian yang bertentangan dengan teori yaitu current ratio tidak berpengaruh signifikan terhadap harga saham.

3. Pengaruh debt to equity ratio terhadap harga saham pada perusahaan industri perhotelan di bursa efek Indonesia

Hipotesis ketiga yang diajukan pada penelitian ini adalah bahwa debt to equity ratio berpengaruh terhadap harga saham pada industri perhotelan di bursa efek Indonesia tahun 20112015. Berdasarkan hasil analisis menunjukkan bahwa debt to equity ratio berpengaruh positif dansignifikan terhadap harga saham pada industri perhotelan di bursa efek Indonesia tahun 2011-2015.

Perusahaan yang sedang tumbuh dan gencar mecari pinjaman-pinjaman untuk pembiayaan investasinya atau pengembangan usaha perusahaan yang konsekuensinya mendorong meningkatnya rasio utang perusahaan yang tinggi. Hal ini dapat mengakibatkan perusahaan dihadapkan kepada risiko yang tinggi juga dalam kemampuan membayar biaya bunga dan cicilan pokok utang. Walaupu rasio utangnya tinggi, perusahaan yang sedang tumbuh dan sangat agresif umumnya diminati banyak investor dan selanjutnya mendorong tingginya permintaan pada saham tersebut, sehingga harga saham perusahaan tersebut akan meningkat tajam. Hal ini mengindikasikan data sampel penelitian ini memiliki harga saham yang mengalami harga saham diatas harga wajar (overvalued )karena angka DER yang bernilai positif. 
Tujuan perusahaan untuk memaksimalkan nilai perusahaan dapat dicapai dengan melaksanakan fungsi-fungsi manajemen. Salah satu keputusan yang harus diambil untuk memaksimalkan nilai perusahaan adalah keputusan pendanaan, dimana perusahaan akan menentukan struktur modal yang terbaik untuk mencapai tujuan perusahaan. Besarnya pengunaan dana eksternal maupun internal akan mempengaruhi nilai perusahaan. Hal ini sesuai dengan hasil penelitian yang menunjukan bahwa DER berpengaruh signifikan terhadap harga saham perusahaan. Hal ini berarti bahwa kenaikan nilai DER dapat meningkatkan harga saham perusahaan secara signifikan.

Hasil temuan ini tidak konsisten dengan hasil penelitian Rahmi et al. (2013) menyatakan bahwa DER berpengaruh signifikan terhadap harga saham. Sejalan dengan penelitian Artha et al. (2014), Puspasari (2005) dengan konsisten menyatakan bahwa debt to equity ratio berpengaruh signifikan terhadap harga saham.

4. Pengaruh IHSG terhadap harga saham pada perusahaan industri perhotelan di bursa efek Indonesia

Hipotesis keempat yang diajukan pada penelitian ini adalah bahwa IHSG berpengaruh terhadap harga saham pada industri perhotelan di bursa efek Indonesia tahun 20112015. Berdasarkan hasil analisis menunjukkan bahwa IHSG berpengaruh positif dan tidak signifikan terhadap harga saham pada industri perhotelan di bursa efek Indonesia tahun 2011-2015.

Indeks harga saham gabungan tidak berpengaruh signifikan terhadap harga saham dapat dikarenakan indeks harga saham gabungan merupakan Indikator pergerakan harga saham yang tercatat di bursa dan merupakan indeks gabungan dari seluruh jenis saham yang tercatat di Bursa Efek Indonesia sehingga tidak mampu memprediksi harga saham secara individual perusahaan yang dijadikan sampel dalam penelitian.

5. Pengaruh volume perdagangan terhadap harga saham pada perusahaan industri perhotelan di bursa efek Indonesia

Hipotesis kelima yang diajukan pada penelitian ini adalah bahwa volume perdagangan berpengaruh terhadap harga saham pada industri perhotelan di bursa efek Indonesia tahun 20112015. Berdasarkan hasil analisis menunjukkan bahwa volume perdagangan berpengaruh positif dan signifikan terhadap harga saham pada industri perhotelan di bursa efek Indonesia tahun 2011-2015.

Hal ini mengindikasikan bahwa semakin banyak jumlah saham yang diperdagangkan menyebabkan harga saham yang meningkat. Peningkatan harga saham yang disebabkan oleh kenaikan volume perdagangan menunjukkan optimisme pasar terhadap sebuah saham. Optimisme pasar inilah yang menyebabkan volume permintaan lebih besar dari pada volume penawaran yang terjadi di bursa. Volume perdagangan dapat dijadikan acuan untuk mempelajari informasi di pasar modal dan penilaian terhadap saham. Hal ini berkaitan dengan keinginan atau motivasi investor dalam melakukan jual beli saham yaitu mendapatkan penghasilan. Volume perdagangan yang kecil mengindikasikan bahwa investor kurang tertarik dalam melakukan investasi, sedangkan volume perdagangan yang besar menunjukkan banyaknya investor yang berminat 
untuk melakukan transaksi jual dan beli saham sehingga harga saham semakin fluktuatif. Dengan demikian hasil penelitian ini konsisten dengan hasil penelitian Abidin et al. (2016) dan Dwi Wulandari (2009).

\section{A. Simpulan}

\section{SIMPULAN DAN SARAN}

Penelitian ini bertujuan untuk melihat pengaruh rasio return on assets, current ratio, debt to equity ratio, IHSG, dan volume perdagangan terhadap harga saham. Populasi yang menjadi objek dalam penelitian ini adalah perusahaan industri perhotelan di bursa efek Indonesia dari tahun 2011 sampai dengan tahun 2015. Berdasarkan pada data yang dikumpulkan dan pengujian yang telah dilakukan maka dapat diambil kesimpulan sebagai berikut:

1. Return on assets berpengaruh positif dan signifikan terhadap harga saham perusahaan industri perhotelan di bursa efek Indonesia dari tahun 20112015.

2. Current Ratio berpengaruh negatif dan tidak signifikan terhadap harga saham perusahaan industri perhotelan di bursa efek Indonesia dari tahun 2011-2015.

3. Debt to equity ratio berpengaruh positif dan signifikan terhadap harga saham perusahaan industri perhotelan di bursa efek Indonesia dari tahun 2011-2015.

4. Indeks harga saham gabungan (IHSG) berpengaruh positif dan tidak signifikan terhadap harga saham perusahaan industri perhotelan di bursa efek Indonesia dari tahun 20112015.

5. volume perdagangan berpengaruh negatif dan signifikan terhadap harga saham perusahaan industri perhotelan di bursa efek Indonesia dari tahun 2011-2015.

\section{B. Saran}

Berdasarkan hasil penelitian maka dapat diberikan beberapa saran berikut:

1. Dalam menjaga kelangsungan hidup perusahaan, maka perusahaan diharapkan melihat pentingnya pengaruh faktor fundamental dan teknikal dalam meningkatkan harga saham. Perusahaan diharapkan memperhatikan faktor-faktor pendukung lainnya yang dapat meningkatkan harga saham.

2. Variabel dari penelitian ini hanya terbatas pada faktor fundamental dan teknikal yang terdiri dari variabel rasio return on assets, current ratio, debt to equity ratio, IHSG, dan volume perdagangan. Diharapkan peneliti selanjutnya untuk menggunakan variabel-variabel lainnya yang dapat mempengaruhi harga saham namun belum diterdapat dalam penelitian ini serta memperpanjang periode penelitian atau menambah sektor perusahaan yang menjadi sampel.

\section{DAFTAR PUSTAKA}

1. Afriyani. 2018. 'Influence of Micro Fundamental Factors and Macroeconomics on Share Return and Manufacturing Value of Companies Listed in Indonesia Stock Exchange (IDX).' Quest journal of research in Humanities and social Science (JRHSS) 6(5): 49-57.

2. Abdullah, A.D.,Hayworth,S.C. 1993, Macroeconometrics of stock price fluctuations, Quarterly Journal of Business and Economics vol 32.

3. Ajayi, Richard A, and Mbodja Mougoue. (1996). On the Dynamic Relation Between Stock Prices and Exchange Rates, The Journal of Financial Reseach, Vol XIX, No. 2, : hal. 193-207.

4. Tjiptono dan Hendy M. Fakhruddin. 
2001. Pasar Modal di Indonesia. Jakarta: Salemba Empat.

5. Darmadji, Tjiptono dan Herdy $\mathrm{M}$. Fakhruddin. 2006. Pasar Modal di Indonesia :Pendekatan Tanya Jawab. Edisi Kedua, Salemba Empat, Jakarta.

6. Dhakal, D.,Mixon, F. \& Upadhyaya, K. 2007. Foreign Direct Investment and Transition Economies: Empirical Evidence from a Panel Data Estimator. Economics Bulletin Vanderbilt Education,Vol. 6, (No.33) : 1-9.

7. Dedi \& Riyatno Setiawan, Doddy. 2003. Analisis Faktor-Faktor Fundamental.

8. Kwon, C.S., T.S. Shin. 1999. "Cointegration and Causality Between Macroeconomic Variables and Stock Market Returns". Global Finance Journal 10, 71.

9. Lipsey,Ragan, dan Courant, 199, suku bunga, harga yang dibayarkan untuk satuan mata uang yang dipinjam pada periode waktu, Erlangga Jakarta.

10. Mankiw, N. Gregory, 2006. Makroekonomi, Edisi Keenam, Erlangga, Jakarta.

11. Nasution, Denga Asmila, 2001, Analisis Hubungan Antara Harga Saham dan Nilai Tukar (Kurs),Tesis, Program Studi Ilmu Ekonomi, Pasca Sarjana Fakultas Ekonomi, Universitas Indonesia.

12. Puspopranoto Sawaldjo.2004. Keuangan Perbankan dan Pasar Keuangan. Jakarta : Pustaka LP3ES Indonesia.

13. Rogalski, R.J. \& Vinso, J.D. 1977, "Stock Returns, Money Suppl y and the Direction of Causality," The Journal of Finance 32, pp. 10171030.

14. Sitepu, Khairin Aurora, 2011. "Pengaruh Nilai Tukar dan Suku
Bunga Terhadap Harga Saham Pada Industri Tekstil di Bursa Efek Indonesia",Medan : Skripsi Fakultas Ekonomi USU

15. Subiyantoro, Edi dan Fransisca Andreani. 2003. Analisis FaktorFaktor Yang Mempengaruhi Harga Saham. Jurnal Manajemen \&Kewirausahaan Vol. 5, No. 2, September 2003: $171-180$

16. Sumiati Ati (2004) Analisis Pengaruh Market Return dan Beberapa Faktor Makro Ekonomi terhadap return Saham (Case Study pada Sarjana Universitas Indonesia.

17. Weston J. Fred dan Eugene F. Brigham. 1993. Dasar-dasar Manajemen Keuangan, Jilid 2, Edisi Kesembilan, Terjemahan oleh Alfonsus Sirait, Jakarta: Erlangga 